\title{
青色光による藻類の炭素代謝の制御
}

(1)

宮 地 重 遠 東京大学応用微生物研究所

神 谷 明 男 帝京大学薬学部教養化学

1. 非光合成的炭素代謝と呼吸に対する青色光効果

1）短時間の青色光によって促進される $\mathrm{C}_{1}-\mathrm{C}_{3}$ 炭素 化反応と呼吸

\section{a ）青色光効果の発見}

1953 年に, ソ連の Voskresenskaya は, ヒマワリの 葉に赤色光 $(580 \sim 720 \mathrm{~nm})$ と青色光 $(400 \sim 575 \mathrm{~nm})$ を それぞれ照射しながら ${ }^{14} \mathrm{CO}_{2}$ 固定を行なわせ，水溶性画 分を分析したところ，青色光は酶酸鉛添加によって沈殿 する分画(タンパク質分画)への ${ }^{14} \mathrm{C}$ のりこみを促進し， 赤色光は, 酢酸鉛処理後の上澄中の中性分画（糖質）へ の ${ }^{14} \mathrm{C}$ のりこみを促進することを見いだした ${ }^{(1)}$.この 結果は，照射光波長による炭素代謝制御の可能性を示す ものであり, 多くの光合成研究者の注目をらけた。しか しながら, Voskresenskaya の結果の追試に成功した研 究者は少なく, 彼女らの研究は, 光合成研究者一般には らけいれられるにはいたらなかった，白色光下で光合成 を行なわせた場合, 弱光条件下では, 強光条件下に拉け るより, 光合成産物中のアミノ酸/炭水化物一比が高くな ることが知られている(2)，ロシアの研究者は，波長効果 を報告する場合にとれぞれの波長による光合成速度や各 波長光の強度を記載していないことが多く，このことが 他の研究者の不信をまねく原因の一つとなった ${ }^{(3)}$.また， Voskresenskaya は, 分析方法の不備のために誤った結 論を得たものと考えた研究者もあった(4).

ただ，カナダの故 Krotkov らは, 単細胞藻類（緑藻 Chlorella vulgaris, C. pyrenoidosa, Scenedesmus acuminatus およびラン藻 Microcystis aeruginosa) を用いて波長効果の研究を行ない，青色光（340６40 $\mathrm{nm})$ はアスパラギン酸, フマール酸への炭酸固定を, 一方, 赤色光 $(580 \sim 700 \mathrm{~nm})$ は, 糖類への炭酸固定を
促進することを明らかにした( ${ }^{(3)}$ 。ただし，彼らの研究に 物いては，単色光を得るために主として色ガラスフィル ターを用いたために, 透過光の波長範囲が広く, 炭素代 謝を制御する波長を特定することが困難であった(5).

小笠原と宮地 ${ }^{(6,7)}$ は, クロレラに干渉フィルターと色 ガラスフィルターを組合せて得た単色光 (半波長幅, 10 $\mathrm{nm}$ 以下）を照射することによって，炭素代謝に対する 波長効果の研究を行なった. Chlorella ellipsoidea 飞, 炭酸固定速度を等しくさせる強さの赤色光 $(679 \mathrm{~nm}, 406$ $\left.\mathrm{erg} / \mathrm{cm}^{2} \cdot \mathrm{sec}\right)$, 青色光 $\left(453 \mathrm{~nm}, 526 \mathrm{erg} / \mathrm{cm}^{2} \cdot \mathrm{sec}\right)$ を それぞれ照射しながら ${ }^{14} \mathrm{CO}_{2}$ を与光, 炭酸固定産物を分 析した結果，赤色光照射下では，青色光照射下に括ける よりもリン酸エステル類, 遊離糖扣よび不溶性画分への ${ }^{14} \mathrm{C}$ のとりこみが顕著であり，一方青色光はアスパラギ ン酸,グルタミン酸特よびリンゴ酸への ${ }^{14} \mathrm{CO}_{2}$ 固定を特 異的に促進することを確認した，さらに彼らは，この青 色光効果が光合成の阻害剂である CMU 存在下でも認め られ, $500 \mathrm{erg} / \mathrm{cm}^{2} \cdot \sec$ 程度の弱光で飽和することを見 いだした．これらの結果は，アスパラギン酸などへの炭 酸固定に関する青色光効果が, 光合成とは無関係な反応 であることを示している.

b）暗スターベーションと青色光効果

青色光下で生成が促進されるアスパラギン酸その他の 産物は， $\mathrm{C}_{1}-\mathrm{C}_{3}$ 炭素化反応の結果生じたオキザロ酢酸 (OAA) 飞由来するものと考兄られる。実際，クロレラ 細胞は， $\mathrm{C}_{1}-\mathrm{C}_{3}$ 炭素化反応を触媒するホスフォエノール ピルビン酸 (PEP) カルボキシラーゼ活性 (EC 4.1.1. 31）を示す. したがって, 炭酸固定に関する青色光効果 は，青色光によって PEP カルボキシラーゼ活性が増大 することによるものと考光た。ささらに笠原と宮地 ${ }^{(8)}$ は, クロレラを 12 時間以上無機培地中で暗中に保つ（暗ス 
ターベーションする）と，著しい青色光効果の認められ ることを見いだした，暗スターベーションなしの細胞で は, 青色光効果が弱いか, 場合によってはまったく青色 光効果の認められない場合がある. 過去の研究者が炭酸 固定に関する青色光効果の観察に成功しなかった理由の 一つは，この暗スターベーション処理をしなかったこと にあるすのと考光られる．暗スターベーション中，一定 時間ごとにクロレラを採取し,リブローズ 1,5 二リン酸 (RuDP) カルボキシラーゼ (EC 4.1.1.39) と PEP カ ルボキシラーゼ活性を測定すると, RuDP カルボキシラ 一ゼ活性は変化しないが，PEPカルボキシラーゼ活性は 暗スターベーション時間の長さに応じて顕著に低下する ことがわかった．この変化に対応して， $\mathrm{CO}_{2}$ の暗固定速 度が顕著に低下したが，光合成活性は変動を示さなかっ た。これらの事実にもとづき，小笠原と宮地は，青色光 を照射しない（上の場合は暗）条件下では, PEP カル ボキシラーゼ活性が低下し，このような細胞に青色光を 照射すると, PEP カルボキシラーゼ活性の増大 (回復), さらには炭酸固定の促進（青色光効果）をるたらすもの と推定した.

\section{c）青色光呼吸との関連}

上述の上うに，炭酸固定に関する青色光効果と光合成 とは無関係な現象である.したがって，この青色光効果 をさらに追究するためには，クロロフィルを含まない細 胞を用いたほうが有利である．神谷と宮地 ${ }^{(9)}$ は，クロロ フィル，カロチノイドを欠いたクロレラの白色突然変異 体（Chlorella vulgaris \#125）を暗スターベーション 処理した後, 青色光を照射すると, 炭酸固定と呼吸が共 に顕著に增加することを見いだした（図 1)．青色光に よる呼吸促進現象は，すで飞緑藻 Chlorella, Scenedesmus のほかに紅藻 Porphyridium でも知られて拈り, 青色光呼吸とよばれている(10).

神谷と宮地は，呼吸拉よび炭酸固定に関する青色光効 果は，次のような共通点をるつことを明らかにしたｉ） 共に暗スターベーション処理によって顕著となる，ii） $500 \mathrm{erg} / \mathrm{cm}^{2} \cdot \mathrm{sec}$ 程度の光で飽和する弱光反応である.

iii）作用スペクトルは，456 nm と $380 \mathrm{~nm}$ 近辺に $2 つ$ の山をもち，互いに非常によくにている(図2-A，B). こ れらの事実は，両青色光効果は共通の機作によってひき おこされることを示唆する．両青色光効果について認め られる唯一の相違点は; 炭酸固定が青色光照射直後直ち

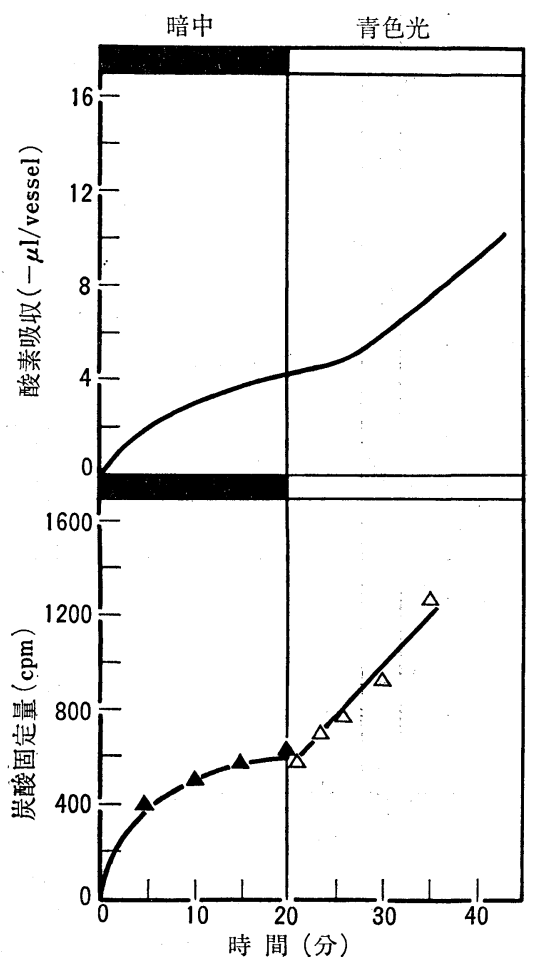

図 1 クロレラ白色変異体細胞 (Chlorella vulgaris \#125）の呼吸と炭酸固定に対する.青色光効果

に促進されるのに対し, 呼吸の促進には数分以上のラグ タイムが認められたことである(図 1). 青色光によって 促進される炭酸固定初期産物は，Chlorella ellipsoidea の野生株同様，アスパラギン酸やリンゴ酸であり，固定 時間が増加するに従って，他の TCA 回路中間体や，そ れらに由来するアミノ酸への炭酸固定も促進された.

\section{d）青色光による炭酸固定と呼吸促進の機作}

これらの事実から神谷と宮地は，青色光による炭酸固 定と呼吸の促進は，以下のような機作によっておこるも のと推定した．まず，青色光によって $\mathrm{C}_{1}-\mathrm{C}_{3}$ 炭素化反 応が促進され，その結果オキザロ酢酸，さらにアスパラ ギン酸拉よび TCA 回路の諸中間体のレベルの上昇をも たらす。TCA 回路中間体レベルの上年とともに酸素吸 収 (呼吸) 速度の促進が括こる。青色光呼吸に認められ たラグタイムは，青色光照射開始後 TCA 回路中間体の レベルが高まるまでに要した時間に相当する.クロレラ 白色細胞にはかなり高い PEP カルボキシラーゼ活性が 認められるが，ピルビン酸カルボキシラーゼ（EC 6.4. 1.1) と PEP カルボキシトランスホスフォリラーゼ (EC 4.1.1.38)活性は検出できなかった(神谷, 宮地 ${ }^{(18)}$ 执よ 

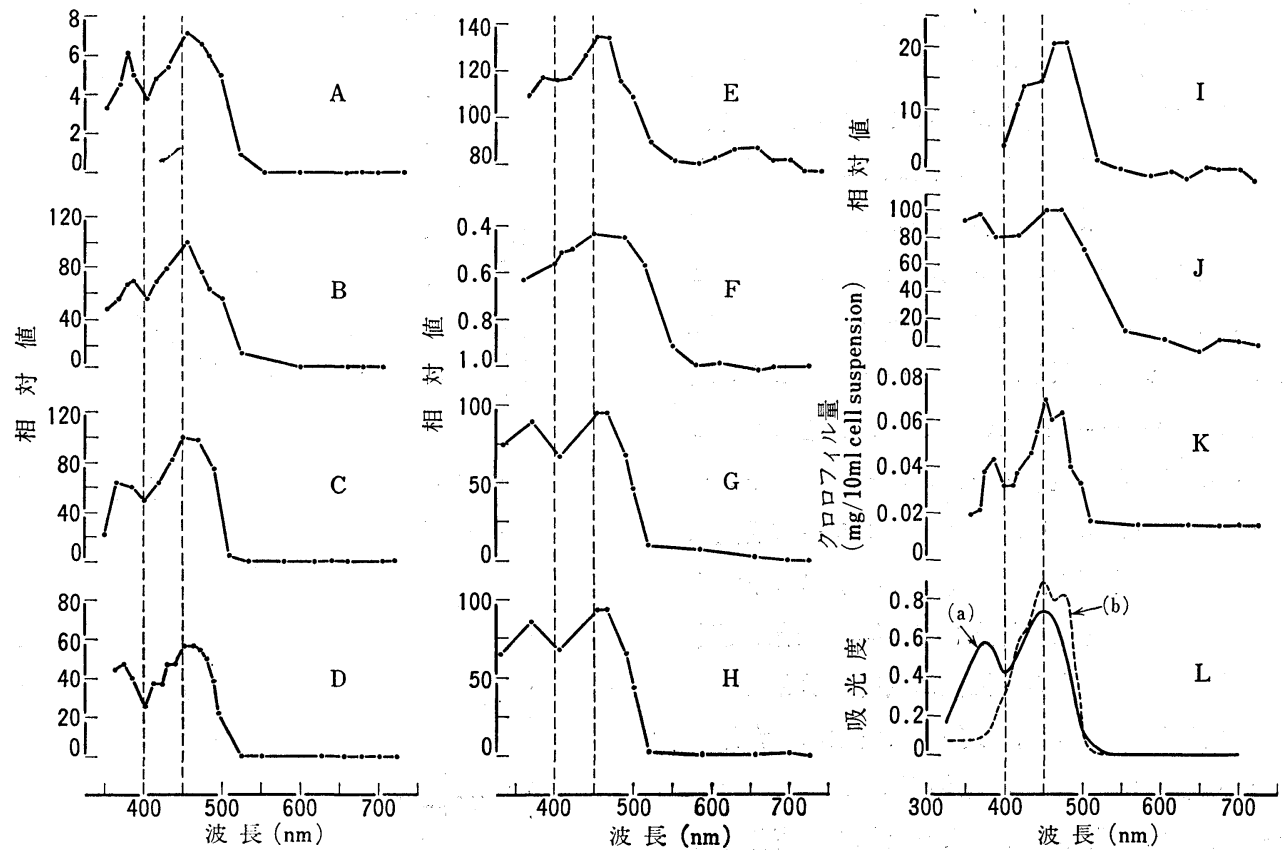

図 2 種々の青色光効果に対する作用スペクトル

A：クロレラ白色変異体の酸素吸収に対する波長効果 ${ }^{(9)}, \quad \mathrm{B} ：$ クロレラ白色变異体の 炭酸固定に対する波長効果 ${ }^{(9)}$, $\mathrm{C}$ ：クロレラ黄色変異体の酸素吸収に対する波長効果 ${ }^{(15)}, \mathrm{D}$ ：クロレラの暗中での酸素吸収に対する前照射光の波長効 果 ${ }^{(16)}, \mathrm{E}$ ：クロレラの酸素発生速度の低下現象に対する波長効果 ${ }^{(17)}, \mathrm{F}: \mathrm{DCMU}$ 存在下でのクロレラの炭水化物・タ ソパク質量比の低下効果 ${ }^{(31)}, \mathrm{G}$ ：クロレラ黄色変異体の炭水化物減少に対する波長効果 ${ }^{(32)}, \mathrm{H}$ ：クロレラ黄色変異体の タンパク質增加に対守る波長効果 ${ }^{(32)}$ ， I ：クロレラ変異体の RNA 合成に対する波長効果 ${ }^{(36)}$ ， J ：クロレラ黄色变異 体のカロチノイド合成に対する波長効果 ${ }^{(39)} ， \mathrm{~K}$ ：セネデスムス変異体のクロロフィル合成に対する波長効果 ${ }^{(40)}, \mathrm{L}:(\mathrm{a})$ フラビンの吸収スペクトル，(b) $\beta$ ーカロチンの吸収スペクトル

び未発表デーダ). したがって，青色光によって促進さ れる $\mathrm{C}_{1}-\mathrm{C}_{3}$ 炭素化反応は, PEP カルボキシラーゼによ って触媒されるものと推定される。

これに関連して,Schmid とSchwarze ${ }^{(11)}$ は, 同じ C. vulgaris の白色変異体の抽出液に FMN とグリシン を添加して青色光を照射すると, 酸素吸収（グリシンの 酸化）が促進されることを見いだした。この知見にもと づいて彼らは，青色光呼吸は青色光によって FMN-グ リシン酸化酵素が活性化されることによってひき抗こさ れると考宎た，彼らの考光は，青色光呼吸に関する作用 スペクトル（図 2-A）が FMN の吸収スペクトルとよ くにていることとも矛盾しない，しかし，彼らは，青色 光によるアミノ酸の酸化促進にはラグタイムがないと報 告している. 一方, 青色光呼吸には数分以上のラグタイ ムが存在する．したがって，アミノ酸の酸化促進を青色 光呼吸と直接結びつけることは困難なように思われる。

e ） アンモニアの添加効果と青色光効果

宮地ら (12) は, アミノ酸の酸化によってアミノ基の放
出が扣こることに注目し，暗スターベーション処理をし たクロレラの白色突然変異体に括ける炭酸暗固定に及ぼ すアンモニアの添加効果をしらべた，その結果，アンモ ニア添加によって, 炭酸暗固定が直ちに顕著に促進され ることが明らかになった（図 3)。また，アンモニア添加 条件下に打ける炭酸固定初期産物には, 青色光照射直後 にお汁ると同様にアスパラギン酸が最も多く、ついでリ ンゴ酸, クェン酸,フマール酸の順に（TCA 回路の中間 体に） ${ }^{14} \mathrm{CO}_{2}$ のとりこみが認められた。このことは，ア ンモニア添加によって，スターブしたクロレラ白色体の $\mathrm{C}_{1}-\mathrm{C}_{3}$ 炭素化反応が促進され, 大部分の固定産物は $\mathrm{TCA}$ 回路の中間体へ移行することを示している，呼吸活性は， アンモニア添加後数分のラグタイムの後に顕著に增加し た. このように，炭酸固定と呼吸に対するアンモニアの 添加効果は, 青色光の効果ときわめてよくにている。こ のことから，もし FMN-アミノ酸酸化酵素に対する青 色光促進効果が青色光呼吸に関与しているとすれば，そ の役割は酸素吸収にではなく、アンモニアの放出にあ 


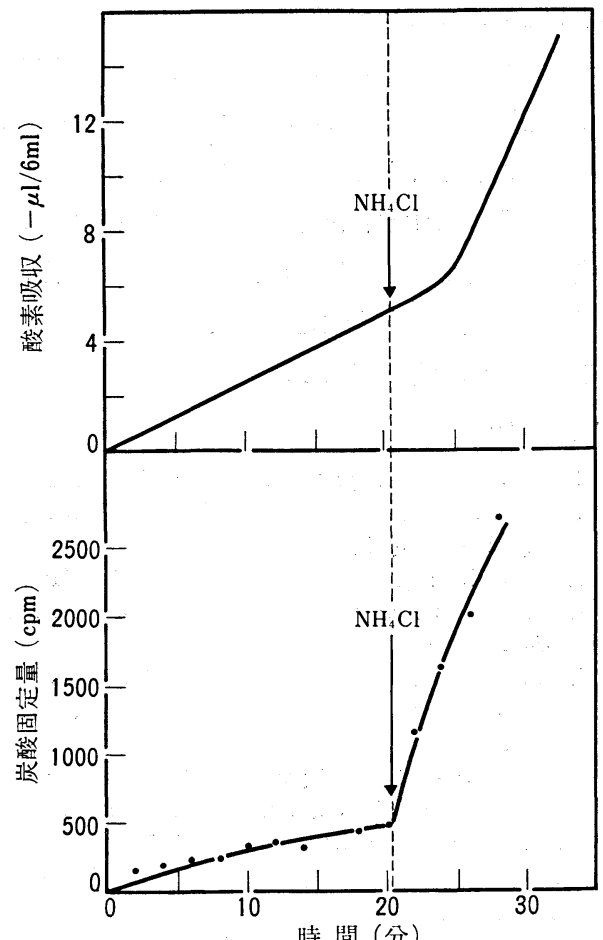

時 間 (分)

図 3 クロレラ白色変異体細胞 (Chlorella vulgaris \#125）の呼吸と炭酸固定に対する塩化アンモニウム 添加効果

り, その結果 OAA の生産が促進されると考えた. 青色 光照射直後におこる酸素吸収量はきわめて小さく, 顕著 な酸素吸収促進は, 青色光照射後数分たって TCA 回路 中間体レベルが高まった後に認められるものと考える.

Hiller ${ }^{(13)}$ と金沢ら ${ }^{(14)}$ は, Chlorella pyrenoidosa 細 胞にアンモニアを添加すると, ピルビン酸キナーゼ活性 が高まることを報告している，このことから，金沢らは， アンモニア添加によってクロレラ細胞内のピルビン酸レ ベルが高まり, その結果ピルビン酸カルボキシラーゼに よる OAA 生成, あるいは NAD (P)ーリンゴ酸酵素 (EC 1.1.1.38(40)）によるリンゴ酸生成が増加する可能性を 指摘した. さらに, ピルビン酸レベルが高まった結果, アセチル CoA の供給が促進され, アセチル CoA と OAA から生成されるクエン酸が，TCA 回路をへてリ ンゴ酸となる過程が促進されることも考えられる。しか し，前にのべたように，クロレラ白色体にはピルビン酸 カルボキシラーゼ活性は検出されなかった. また, 後者 の二つの可能性は, アンモニア存在下に打ける ${ }^{14} \mathrm{CO}_{2}$ 固 定初期産物がリンゴ酸でなく，アスパラギン酸であった 事実 ${ }^{(12)}$ と一致しない.

\section{f ）青色光呼吸とグリコール酸排出との関連}

Kowallik ${ }^{(15)}$ は，クロロフィルを欠くがカロチノイド を含む Chlorella vulgaris の黄色突然変異体（\#211） を暗スターベーション処理し，呼吸促進に関する作用ス ペクトルを求めた (図 2-C). また, Pickett と French(16) および Kowallik と Kowallik ${ }^{(17)}$ お，それぞれChlorella pyrenoidosa の野生株を用い，それぞれ種々の波長光を 照射した值後に拉ける暗中の酸素吸収括よび種々の波長 光を 15〜20 分間照射した場合に認められる $\mathrm{O}_{2}$ 発生速 度の初速度からの低下現象（赤色光ではまったく認めら れず，青色光下でのみ認められ，したがって青色光照射 による呼吸促進を反映すると考えられる）に関する作用 スペクトルを求めた（図 2-D, E). これらの作用スペク トルは, クロレラ白色突然変異体を用いて得た酸素吸収 促進に関する作用スペクトルときわめてよく一致してい る.これらの事実は, 野生株, 突然変異体の種類を問わ ず, 青色光呼吸の機作は同一であることを示唆する．ま た, Kowallik(10) は, クロレラの黄色突然変異体に嫌気 条件下で青色光を前照射した後，好気条件にらつすと， 暗呼吸が促進されることを見いだした，さらに彼は，青 色光前照射中に黄色突然変異体懸垂液の $\mathrm{pH}$ が低下する こと，特よび $\mathrm{pH}$ 低下の原因がグリュール酸の排出によ ることを報告している。したがって，彼は，青色光前照 射中にグリコール酸が細胞外へ排出され，好気条件にも どすと，それが再び細胞内へとりこまれて呼吸の促進を ひき特こすと考えた。

都筑と宮地 (未発表) は, クロレラの白色変異体を用 いて, 彼の結果を追試した. 白色突然変異体に和いても, 嫌気条件下で青色光を前照射し，照射を停止すると同時 に好気条件にもどすと，顕著な暗呼吸促進が認められた。 また，青色光前照射によって突然変異体䀣垂液の $\mathrm{pH}$ 低 下も認められた。さらに，嫌気条件下で青色光を前照射 した突然変異体懸垂液を遠心し，得られた上澄を他の突 然変異体懸垂液に添加すると，顕著な暗呼吸促進のおこ ることも認められた。 しかし，白色突然変異体をリン酸 緩衝液に懸垂し，一定時間ごとに一定量の懸垂液をとり 出し, スターベーション処理の長さと, 青色光前照射に よる上記諸効果との関係をしらべた結果，青色光前照射 による $\mathrm{pH}$ 低下は, スターベーション処理をしない細胞 に最も顕著であり，スターベーション処理時間が長くな るに従って $\mathrm{pH}$ 低下度が減少し，3 日スターブした細胞 


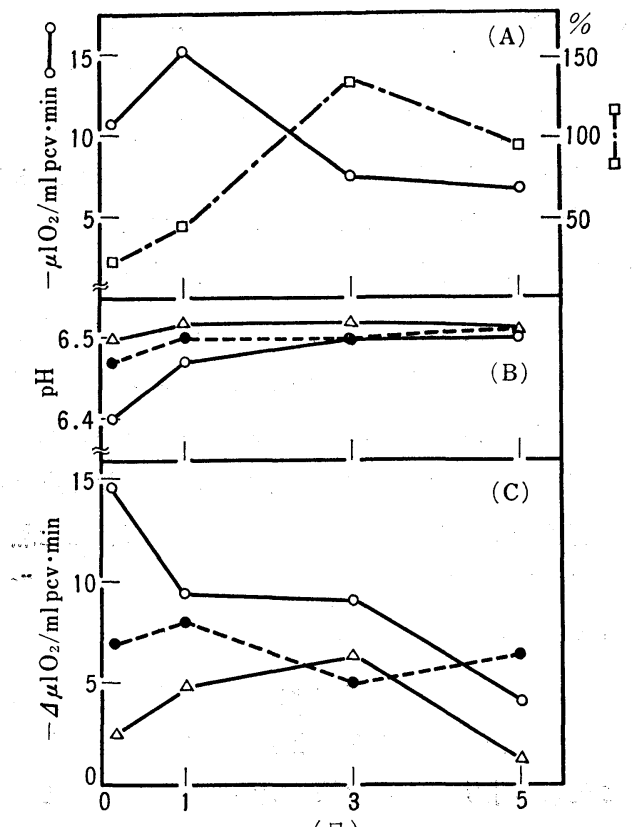

(日)

図 4 青色光呼吸と青色光照射による培地の $\mathrm{pH}$ 低 下現象との関連

(A) スターペーションの日数と，暗呼吸速度 (○一○) および呼吸に対する青色光効果（口-

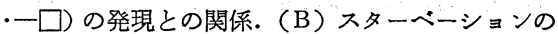
日数と, 120 分間青色光照射処理（嫌気条件下， ○一○）打よび暗（嫌気条件下，○……好気 条件下, $\triangle-\triangle$ ) 処理後の細胞眯垂液 (上澄) の $\mathrm{pH}$ との関連. (C) (B)で得られた上澄添加によ る暗呼吸促進度. 暗処理してない細胞懸垂液 $4 \mathrm{ml}$ に，(B)で得られた上澄を 4 倍に濃 縮したもの $0.25 \mathrm{ml}$ を添加した. 記号は (B) と同じ.

では $\mathrm{pH}$ 低下がほとんどおこらないことが明らかになっ た（図 4-B）。また，青色光を前照射した細胞懸垂液の上 澄添加による暗呼吸促進度も，スターベーション処理を 長くするに従って低下する傾向があった（図 4-C，ただ しこの場合は， $\mathrm{pH}$ 低下の場合ほど明確なスターベーシ ョン時間との相関性を示さず，スターベーション開始後 1あるいは 2 日目の細胞を前照射すると, 最大添加効果
を示すこともあった)，一方，呼吸に対する青色光効果は スターベーション処理時間が長くなるに従って顕著とな り，3 日後に最大の効果がみられた (図 4-A $)^{(9)}$. これ らの事実は，少なくともクロレラの白色突然変異体に和 いては，呼吸に対する青色光効果と，嫌気条件下に拉い て細胞を青色光照射した場合に認められる $\mathrm{pH}$ 低下执よ び呼吸促進物質の排出現象とは，互いに関係のない現象

であることを示すものである.

(つづく)

\section{文献}

1) N. P. Voskresenskaya : Nichiporovich, A. A., Proc. Internat'l Conf. Peaceful Uses of Atomic Energy, 12, 340 (1955) から引用.

2) I. Horváth \& K. Szász: Nature, 207, 546 (1965).

3) G. Krotkov : Trans. Roy.Soc.Canada, 4th Ser., 2, 205 (1964).

4) T. Cayle \& R. Emerson: Nature, 179, 89 (1957).

5) J. L. Hess \& N. E. Tolbert : Plant Physiol., 42, 1123 (1967).

6) N. Ogasawara \& S. Miyachi : in "Progress in Photosynthesis Res. 3", ed. by. H. Metzner, Verlag C. Lichtenstern, München, 1969, p. 1653.

7) N. Ogasawara \& S. Miyachi : Plant \& Cell Physiol., 11,1 (1970).

8) N. Ogasawara \& S. Miyachi : Plant \& Cell Physiol., 12, 675 (1971).

9) A. Kamiya \& S. Miyachi : Plant \& Cell Physiol., 15, 927 (1974).

10) W. Kowallik: in "Photosynthesis and Photorespiration", ed. by M. D. Hatch, C. B. Osmond and R. O. Slatyer, Wiley-Interscience, New York, 1971, p. 165.

11) G.H. Schmid \& P. Schwarze: Hoppe-Seyler's Z. Physiol. Chem., 350, 1513 (1969).

12) S. Miyachi, A. Kamiya \& Shizuko Miyachi : "Biological Solar Energy Conversion", ed. by A. Mitsui et al., Academic Press, New York, 1977, p. 167.

13) R. G. Hiller : J.Exp. Bot., 21, 628 (1970).

14) T. Kanazawa, K. Kanazawa, M. R. Kirk \& J.A. Bassham : Biochim. Biophys. Acta, 256, 656 (1972).

15) W. Kowallik: Plant Physiol., 42, 672 (1967).

16) J. M. Pickett \& C. S. French : Proc. Natl. Acad. Sci., 57, 1587 (1967).

17) U. Kowallik \& W. Kowallik: Planta, 84, 141 (1969).

18) A. Kamiya \& S. Miyachi : Plant \& Cell Physiol., 16, 729 (1975).
化学 と生物 Vol. 15, No. 10 (167 号)

昭和 52 年 10 月 25 日発行

$$
\text { （月 刊）定価 } 450 \text { 円 }
$$

編集者：社団法人日本農芸化学会

発行者：財団法人東京大学出版会

113 東京都文京区本郷 7-3-1 (東大構内)

印刷者：新日本印刷株式会社

装幀・鈴木 堯, 插図・伊藤 允三
企画委員 ${ }^{\circ}$ 有 馬 啓, 有吉修二郎, 一島 英治, 上田誠之助, 梅田 圭司, 大村栄之助, 岡 田 弘, 岡見 吉郎, 賀田 恒夫, 勝部 泰次, 鬼頭 誠, 木村 修一, 後藤 “俊夫, 鮫島 広年, 鈴木 昭憲, 曾根 敏麿, 高橋“英一, 高橋 信孝, 田村 善蔵, 茅野 充男, 戸田 昭三, 樋口隆昌, 丸茂 晋吾, 丸山 工作, 水谷 純也, 宮尾 興平, 宮崎 基嘉, 村地 孝, 山本 武彦, 吉武 成美 企画理事相田浩

○企画委員長 